\title{
PENGARUH PIJAT PERINEUM TERHADAP KEJADIAN RUPTUR PERINEUM PADA IBU BERSALIN PRIMIPARA DI BPM NY "I" CIPAGERAN CIMAHI UTARA KOTA CIMAHI JAWA BARAT
}

\author{
Risza Choirunissa ${ }^{1)}$, Suprihatin ${ }^{2)}$, Han Han $^{3)}$ \\ Faculty of Health Science, Nasional University Jakarta \\ risza.choirunissa@gmail.com
}

\begin{abstract}
ABSTRAK
Salah satu penyebab morbiditas dan mortalitas ibu adalah infeksi pada masa nifas dimana infeksi tersebut berawal dari ruptur perineum. Berdasarkan hasil data di BPM "I" tahun 2017 terdapat ibu hamil 1.201, jumlah ibu bersalin sebanyak 290 orang. Jumlah ibu yang mengalami ruptur perineum saat persalinan sebanyak 155 orang (53,5\%). Jumlah ibu bersalin primipara yang mengalami ruptur perineum sebanyak 109 orang (37,6\%), dan jumlah ibu bersalin multipara yang mengalami ruptur perineum sebanyak 46 orang $(15,9 \%)$. Tujuan dari penelitian ini yaitu Untuk mengetahui pengaruh pijat perineum terhadap kejadian ruptur perineum pada ibu bersalin primipara di BPM Ny."I" Cipageran Cimahi Utara Kota Cimahi. Metodologi Penelitian ini menggunakan rancangan pre-eksperimen the static Group Comparison dengan membagi dua kelompok, yaitu kelompok intervensi dan kelompok kontrol. Sampel dalam penelitian ini berjumlah 30 orang ibu hamil yang terdiri dari 15 orang kelompok intervensi dan 15 orang kelompok kontrol. Teknik pemilihan sampel dengan menggunakan total sampling. Instrumen penelitian terdiri dari dokumentasi, booklet, lembar observasi serta lembar partograf. Data dianalisis menggunakan Independent $t$ test untuk mengetahui perbedaan pengaruh antar kelompok. Hasil penelitian menunjukkan bahwa terdapat pengaruh antara pijat perineum dengan kejadian ruptur perineum dengan hasil signifikansi 0,028 $(p<0.05)$. Simpulan dan Saran yang dapat diberikan yaitu pijat perineum dapat mencegah terjadinya ruptur perineum pada persalinan normal. Program ini dapat diaplikasikan di praktik klinik kebidanan khususnya pada ibu hamil primigravida.
\end{abstract}

Kata Kunci: Pijat Perineum, Ruptur Perineum.

\section{PENDAHULUAN}

Data World Health Organization (WHO) menunjukkan di Indonesia tercatat 190 Kematian ibu setiap 100.000 kelahiran hidup pada tahun 2013, Berdasarkan hasil Survei Demografi dan Kesehatan Indonesia (SDKI, 2012) Angka Kematian Ibu (AKI) mencapai 359 per 100.000 kelahiran hidup, AKI di Jawa Barat terlaporkan sebanyak 799 orang $(84,78 / 100.000 \mathrm{KH})$, dengan proporsi kematian pada ibu hamil 227 orang (20,09/100.000), pada ibu bersalin 202 orang (21,43/100.000 KH), dan pada ibu nifas 380 orang (40,32/100.000 KH), jika dilihat berdasarkan kelompok umur presentasi kematian pada kelompok umur 35 tahun sebanyak 219 orang (27,41\%) (Dinkes Jabar, 2016).

Angka kematian ibu pada tahun 2016 di Kota Cimahi tercatat sebesar 8 dari 10.341 kelahiran hidup atau sekitar 77,3/100.000 kelahiran hidup dan angka kematian bayi tercatat sebesar 66 dari 10.341 kelahiran hidup atau 6,3/1.000 kelahiran hidup (Dinkes Cimahi, 2016).

Menurut Dinas Kesehatan Kota Cimahi pada tahun 2015 melaporkan dari bulan Januari - Desember jumlah ibu hamil dengan risiko tinggi tercatat sebanyak 2,369 dari 11,844 ibu hamil, terdapat 11,378 (90,06\%) tidak mengalami komplikasi, ada 211 (1,8\%) ibu hamil mengalami KEK, 157 (1,32\%) mengalami anemia sedangkan ibu hamil dengan protein urin positif terdapat $90(0,8 \%)$, dan ibu hamil yang mengalami Diabetes Melitus (DM) terdapat $4(0,03 \%)$, ibu hamil dengan HIV positif ada $2(0,01 \%)$, serta yang mengalami TB positif ada $2(0,01 \%)$ (Rekapan data Bumil di Kota Cimahi tahun 2015).

Hermiyanti (2010), mengatakan penyebab langsung kematian ibu terkait persalinan adalah perdarahan 
(28\%). Sebab lain, yaitu eklamsi (24\%), infeksi (11\%), partus lama (5\%), dan abortus (5\%). Penyebab perdarahan pasca persalinan yaitu karena gangguan pada rahim, pelepasan plasenta, ruptur jalan lahir, dan gangguan pembekuan darah. Resiko akan meningkat pada ibu hamil yang menderita anemia dan rahim teregang terlalu besar karena bayi besar.

Dampak dari robekan perineum antara lain meningkatkan pendarahan, menambah dalamnya laserasi perineal, menambah resiko kerusakan spincher ani, menambah rasa sakit pada hari-hari pertama masa post partum, dan meningkatkan resiko infeksi. Robekan jalan lahir juga diakibatkan oleh robekan spontan perineum, trauma forsep atau vakum ekstraksi, versi ekstraksi dan episiotomi (Yanti , 2010). Ciri yang khas dari robekan perineum yaitu kontraksi uterus kuat, keras dan mengecil, pendarahan terjadi langsung setelah anak lahir ( Depkes, 2012). Data dari Depkes RI (2012) dari rentang tahun 2009-2010 tercatat 106.461 ibu yang melahirkan dan 26.383 ibu mengalami kasus episiotomi.

Pencegah perlukaan perineum bisa dicegah dengan dilakukannya pijat perineum. Pijat perineum adalah teknik memijat perineum di saat hamil atau beberapa minggu sebelum melahirkan guna meningkatkan perubahan hormonal yang melembutkan jaringan ikat, sehingga jaringan perineum lebih elastis dan lebih mudah meregang. Teknik ini dapat dilakukan satu kali sehari selama beberapa minggu terakhir kehamilan di daerah perineum (area antara vagina dan anus (Aprilia, 2010).

Manfaat dari pijat perineum yaitu mencegah terjadinya ruptur perineum maupun episiotomi. Pijat perineum juga dapat meningkatkan aliran darah, melunakkan jaringan di sekitar perineum ibu dan membuat elastis semua otot yang berkaitan dengan proses persalinan termasuk kulit vagina. Saat semua otot-otot itu menjadi elastis, ibu tidak perlu mengejan terlalu keras cukup pelan-pelan saja bahkan bila prosesnya lancar ruptur pada perineum tidak terjadi dan vagina tidak perlu dijahit (Indivara, 2009).

Penelitian oleh Beckmann dan Garett tahun 2006 (dalam Burns, 2011) menunjukkan bahwa pijat perineum di usia 35 minggu kehamilan, dapat mengurangi kemungkinan trauma perineal yang membutuhkan jahitan. Umumnya wanita mengeluh kesakitan pada perineal di tiga bulan pasca kelahiran. Ibu-ibu yang rajin melakukan pijat perineum sejak 3 bulan sebelum hari-H persalinan, terbukti hampir tidak ada yang mengalami robekan perineum, kalaupun terjadi perobekan perineum secara alami, maka luka pulih dengan cepat. Wanita yang melakukan pijat perineum juga mengalami penurunan resiko dari trauma yang cukup berat dari episiotomi (Elsevier, 2009).

Penelitian yang diterbitkan di Amerika Journal Obstetrician and Gynecology menyimpulkan bahwa pijat perineum selama kehamilan dapat melindungi fungsi perineum paling tidak dalam 3 bulan pascamelahirkan. The Cochrane Review merekomendasikan bahwa pijat perineum ini harus selalu dijelaskan pada ibu hamil agar mereka mengetahui keuntungan dari pijat perineum ini. Pijat perineum ini sangat aman dan tidak berbahaya (Herdiana, 2007).

Berdasarkan data di BPM Ny. "I" bahwa kejadian ruptur perineum pada primigravida lebih banyak karena perineum kaku atau kurang elastis terutama primigravida karena vagina belum pernah dilewati oleh janin sehingga vagina harus meregang sedemikian rupa untuk mengeluarkan janin dapat mengakibatkan ruptur perineum karena di BPM Ny.' I'" tidak pernah melakukan pijat perineum. Oleh karena itu penulis tertarik dan bermaksud untuk melakukan Penelitian tentang "Pengaruh Pijat Perineum Terhadap Kejadian Ruptur 
Perineum Pada Ibu Bersalin Primipara di BPM Ny. "I" Cipageran Cimahi Utara Kota Cimahi "

\section{METODE}

\section{Desain Penelitian}

Desain penelitian ini menggunakan rancangan pre-eksperimen the static Group Comparison, yaitu penelitian variabel dengan membagi dua kelompok, yaitu kelompok eksperimen dan kelompok kontrol. penelitian yang digunakan untuk mencari pengaruh perlakuan tertentu terhadap yang lain dalam kondisi yang terkendalikan (Sugiyono, 2011).

\section{Populasi dan Sampel}

\section{Populasi}

Populasi adalah keseluruhan obyek penelitian atau obyek yang diteliti (Arikunto, 2013). Populasi dalam penelitian ini adalah seluruh ibu hamil primigravida usia kehamilan 35-36 minggu sebanyak 30 orang di BPM Ny.“I” Cipageran Cimahi utara Kota Cimahi tahun 2019 selama bulan Januari-Maret.

\section{Sampel}

Sampel adalah sebagian atau wakil populasi yang diteliti (Arikunto, 2013).

Teknik pengambilan sampel dalam penelitian ini adalah total sampling. Total sampling adalah teknik pengambilan sampel dimana jumlah sampel sama dengan populasi (Sugiyono, 2007). Alasan mengambil total sampling karena menurut Sugiyono (2007).

jumlah populasi yang kurang dari 100 seluruh populasi dijadikan sampel penelitian semuanya. Responden dalam penelitian ini semuanya sebanyak 30 orang dan dibagi menjadi 2 kelompok yakni 15 orang kelompok intervensi dan 15 orang kelompok kontrol dengan kriteria inklusi dan eksklusi tertentu.

\section{Lokasi dan Waktu Penelitian}

\section{Lokasi Penelitian}

Penelitian ini dilaksanakan di BPM Ny. "I" Cipageran Cimahi Utara Kota Cimahi Jawa Barat.

\section{Waktu Penelitian}

Penelitian ini telah dilakukan pada Bulan Desember 2018 sampai dengan Bulan Maret 2019.

\section{Variabel penelitian}

Variabel dalam penelitian ini terdiri dari variabel independent atau variabel bebas dalam adalah pijat perineum dan variabel dependen atau variabel terikat adalah kejadian ruptur perineum pada ibu bersalin primipara.

\section{Prosedur Pengumpulan Data}

Data mengenai pemijatan perineum diperoleh melalui wawancara langsung pada pasien. Sedangkan untuk memperoleh banyaknya ibu hamil primigravida dengan usia kandungan 35-36 minggu menggunakan data sekunder yang diperoleh dari catatan medis BPM..

\section{Pengolahan dan Analisis Data}

Data yang telah diperoleh dari hasil pemberian pijat perineum kemudian dilakukan pengolahan data. Analisis yang dilakukan dalam penelitian ini adalah analisi univariat dan bivariat, sebelum dilakukan uji bivariat 
maka dilakukan uji normalitas data sabagai prasyarat uji parametrik.

Uji normalitas dalam penelitian ini menggunakan uji Kolmogorov-smirnov dengan cara melihat nilai asymp sig (2-tailed) dengan hasil 0,276 yang artinya > 0,05 maka dapat dikatakan hasil berdistribusi normal. Maka uji statistik yang digunakan adalah uji parametrik yaitu Independent $T$ Test.

\section{HASIL DAN PEMBAHASAN}

\section{Hasil Penelitian}

\section{Analisis Univariat}

Analisis univariat disajikan dalam bentuk distribusi frekuensi dan presentase dari masing-masing kategori setiap variabel yang menjadi perhatian dalam penelitian ini, hasil penelitian pada analisis univariat disajikan sebagai berikut:

Tabel 1

Karakteristik Responden

\begin{tabular}{llll}
\hline \multicolumn{1}{c}{ Karakteristik Responden } & \multicolumn{2}{c}{ Kelompok Intervensi } & Kelompok Kontrol \\
\hline Umur & $<20$ & $6,7 \%$ & $6,7 \%$ \\
\cline { 2 - 4 } & $20-35$ & $93,3 \%$ & $93,3 \%$ \\
\hline & $>35$ & 0 & 0 \\
\hline Pendidikan & SMP & $26,7 \%$ & $26,7 \%$ \\
\cline { 2 - 4 } & SMA & $66,7 \%$ & $60.0 \%$ \\
\cline { 2 - 4 } & DIPLOMA & $6,7 \%$ & $6,7 \%$ \\
\hline Pekerjaan & SARJANA & 0 & $6,7 \%$ \\
\hline \multirow{2}{*}{} & IRT & $86,7 \%$ & $66,7 \%$ \\
\hline & Karyawan & $13,3 \%$ & $26,7 \%$ \\
\hline & Swasta & 0 & $6,7 \%$ \\
\hline
\end{tabular}

Berdasarkan Tabel 1 diatas menunjukan bahwa responden pada kelompok intervensi sebagian besar berumur 20-35 tahun sebanyak 14 orang (93,3\%), berdasarkan tingkat pendidikan terakhir responden paling banyak 10 orang $(66,7 \%)$, berdasarkan pekerjaan mayoritas Ibu Rumah Tangga sebanyak 13 orang $(86,7 \%)$. Sedangkan pada kelompok kontrol sebagian besar berumur 20-35 tahun sebanyak 14 orang $(93,3 \%)$, tingkat pendidikan terakhir sebagian besar 9 orang $(60,0 \%)$ dan sebagian besar responden sebagai Ibu Rumah Tangga sebanyak 10 orang $(66,7 \%)$.

Tabel 2

Berat Badan Bayi Lahir

\begin{tabular}{|c|c|c|c|}
\hline \multicolumn{2}{|c|}{ Faktor Confounding } & $\frac{\text { Kelompok Intervensi }}{\%}$ & $\frac{\text { Kelompok Kontrol }}{\%}$ \\
\hline \multirow{3}{*}{$\begin{array}{l}\text { Berat Badan } \\
\text { Bayi Lahir }\end{array}$} & $<2500$ & $13.3 \%$ & $67 \%$ \\
\hline & $2500-4000$ & $86.7 \%$ & $93.3 \%$ \\
\hline & $>4000$ & & \\
\hline Total & & $100.0 \%$ & $100.0 \%$ \\
\hline
\end{tabular}

Berdasarkan Tabel 2 menunjukan bahwa faktor confounding menurut berat badan bayi lahir pada kelompok intervensi sebagian besar beratnya 2500-4000 gram sebanyak 13 orang (86,7 \%), sedangkan pada kelompok kontrol sebagian besar beratnya 2500-4000 gram sebanyak 14 orang (93,3\%). 


\section{Analisis Bivariat}

Analisis bivariat dilakukan untuk mengetahui ada atau tidak pengaruh pemberian pijat perineum terhadap kejadian ruptur perineum pada ibu bersalin primipara dengan menggunakan anailis Uji Independen T-Test

Tabel 3

Pengaruh Pijat Perineum Terhadap Kejadian Ruptur Perineum Pada Ibu Besalin Primipara Antara Kelompok Intervensi dan Kontrol

\begin{tabular}{lcccc}
\hline \multirow{2}{*}{ Derajat Ruptur Perineum } & \multicolumn{2}{c}{$\begin{array}{c}\text { Kelompok } \\
\text { Intervensi }\end{array}$} & \multicolumn{2}{c}{ Kelompok Kontrol } \\
\cline { 2 - 5 } & $\mathbf{n}$ & $\boldsymbol{\%}$ & $\mathbf{n}$ & \% \\
\hline Tidak Ruptur Perineum & 11 & 73,3 & 5 & 33,3 \\
\hline Ruptur Perineum Derajat I & 1 & 6,7 & 4 & 26,7 \\
\hline Ruptur Perineum Derajat II & 3 & 20,0 & 6 & 40,0 \\
\hline Ruptur Perineum derajat III & 0 & 0 & 0 & 0 \\
\hline Total & 15 & 100 & 15 & 100 \\
\hline
\end{tabular}

Berdasarkan Tabel 3 menunjukan bahwa kejadian ruptur perineum lebih banyak pada kelompok kontrol sebanyak 10 orang $(66,7 \%)$ yang tidak dilakukan pemijatan perineum dibandingkan pada kelompok intervensi 4 orang $(26,7 \%)$ yang dilakukan pemijatan perineum.

Tabel 4

Hasil Uji Independent T Test

\begin{tabular}{lcccc}
\hline \multirow{2}{*}{ Kelompok } & \multicolumn{2}{c}{$\begin{array}{c}\text { Ruptur } \\
\text { Perineum }\end{array}$} & t score & P \\
\cline { 2 - 3 } & $\mathbf{M}$ & Sd & & \\
\hline $\begin{array}{l}\text { Kelompok } \\
\text { Intervensi }\end{array}$ & 0.27 & 0.458 & -2.316 & 0.028 \\
\hline $\begin{array}{l}\text { Kelompok } \\
\text { Kontrol }\end{array}$ & 0.67 & 0.488 & -2.316 & \\
\hline
\end{tabular}

Berdasarkan Tabel 4 dari hasil uji statistik diatas diketahui nilai signifikansi 0,028 yang artinya $p<0,05$ maka dapat disimpulkan bahwa terdapat pengaruh antara pijat perineum dengan kejadian ruptur perineum.

\section{Pembahasan}

\section{Analisis univariat}

\section{Usia}

Berdasarkan penelitian ini maka diperoleh karateristik primigravida berdasarkan umur sebagian besar berumur 20-35 tahun pada kelompok intervensi sebanyak 14 responden (93,3\%) dan pada kelompok kontrol sebanyak 14 responden (93,3\%). Pada usia reproduktif (20-35 tahun) pada saat ini respon ibu untuk menerima pengertian tentang pemijatan perineum, manfaat dan cara pemijatan perineum lebih efektif dan dapat mempelajarinya.

Menurut Hurlock (2011), bahwa usia reproduktif (20-35 tahun) terjadi kesiapan respon maksimal baik dalam menyesuaikan hal-hal tertentu dan sedikit demi sedikit menurun seiring dengan bertambah umur. Selain itu pada usia reproduktif mereka lebih terbuka terhadap orang lain dan biasanya mereka akan saling 
bertukar pengalaman tentang hal yang sama yang pernah mereka alami.

\section{Pendidikan}

Distribusi pendidikan responden pada kelompok intervensi sebagian besar berpendidikan terakhir SMA sebanyak 10 responden $(66,7 \%)$ dan pada kelompok kontro sebagian besar berpendidikan terakhir SMA sebanyak 9 responden $(60,0 \%)$. Rendahnya tingkat pendidikan menyebabkan tingkat pengetahuan responden masih kurang.

Menurut Notoatmodjo (2012), tingkat pendidikan dapat mempengaruhi tingkat pengetahuan responden oleh karena kemampuan seseorang dalam menerima dan memahami ditentukan oleh tingkat pendidikan yang dimiliki. Penerimaan dan pemahaman terhadap informasi yang diterima seseorang yang berpendidikan tinggi lebih baik dibandingkan dengan seseorang yang berpendidikan rendah.

\section{Pekerjaan}

Berdasarkan karakteristik pekerjaan pada penelitian ini sebagian besar responden pada kelompok intervensi berprofesi sebagai ibu rumah tangga sebanyak 13 responden $(86,7 \%)$ dan pada kelompok kontrol sebanyak 10 responden $(66,7 \%)$. Wanita hamil tetap dapat bekerja namun aktivitas yang dijalaninya tidak boleh terlalu berat. Istirahat untuk wanita hamil dianjurkan sesering mungkin.

Seorang wanita hamil disarankan untuk menghentikan aktivitasnya apabila mereka merasakan gangguan dalam kehamilan. Pekerjaan yang membutuhkan aktivitas berat, berdiri dalam jangka waktu lama, pekerjaan dalam industri mesin, atau pekerjaan yang memiliki efek samping lingkungan harus dimodifikasi (Sulistyawati, 2009).

\section{Berat Badan Bayi Lahir}

Berat badan bayi lahir dapat mempengaruhi robekan perineum terutama pada bayi besar. Berat bayi yang normal yaitu antara 2500-4000 gram juga dapat menyebabkan terjadinya robekan perineum. Bayi baru lahir yang terlalu besar atau lebih dari 4000 gram akan meningkatkan resiko proses persalinan yaitu kemungkinan bahu bayi tersangkut, bayi akan lahir dengan gangguan nafas dan keadaan bayi lahir dengan trauma leher, bahu dan syarafnya. Hal ini terjadi karena berat bayi yang besar sehingga sulit melewati panggul dan menyebabkan terjadinya robekan perineum pada ibu bersalin normal (Enggar, 2010).

\section{Analisis bivariat}

\section{Pengaruh Pijat Perineum Terhadap Ruptur Perineum}

Berdasarkan hasil penelitian yang dilakukan oleh peneliti dan telah dianalisis menggunakan uji normalitas $z$ Kolmogorov Smirnov dan uji Independent T Test. Menunjukan bahwa terdapat pengaruh pemijatan perineum pada ibu hamil primigravida terhadap kejadian ruptur perineum saat persalinan antara kelompok intervensi dan kelompok kontrol. Hasil penelitian menunjukkan bahwa pada kelompok kontrol sebanyak 10 orang $(66,67,0 \%)$ mengalami ruptur perineum. Sedangkan pada kelompok intervensi jumlah responden yang mengalami ruptur perineum hanya 4 orang $(26,7 \%)$ yaitu derajat I sebanyak 1 orang dan derajat II sebanyak 3 orang.

Menurut Mochtar (2011) perineum yang kaku dan tidak elastis akan menghambat persalinan kala II dan dapat meningkatkan risiko terhadap janin serta dapat menyebabkan robekan perineum yang luas sampai tingkat III. Perineum yang lunak dan elastis serta cukup lebar, pada umumnya tidak memberikan kesukaran 
pengeluaran kepala janin, jika terjadi robekan hanya sampai derajat 1 dan derajat II.

Jumlah responden pada kelompok intervensi yang tidak mengalami laserasi perineum sebanyak 11 orang (73,33\%) lebih banyak dibandingkan pada kelompok responden kontrol sebanyak 5 orang $(33,33 \%)$. Banyaknya responden kelompok intervensi yang tidak terjadi laserasi perineum setelah melakukan pemijatan perineum mulai usia kehamilan 35/36 minggu, hal ini dapat dipengaruhi oleh tingkat kepatuhan responden dalam mempraktikkan teknik pijat perineum dengan frekuensi pemijatan 5 kali dalam setiap minggu.

Sesuai dengan pendapat Beckmann \& Stock (2013) bahwa wanita yang melakukan pijat perineum mulai usia kehamilan 35 minggu mempunyai risiko lebih kecil terjadi trauma jalan lahir pada persalinan normal dan secara statistik signifikan dapat $16 \%$ mengurangi kejadian dilakukan episiotomi. Hasil penelitian yang sama dilakukan oleh Savitri W, Ermawati, Yusefni E. (2015) bahwa kejadian ruptur perineum pada kelompok intervensi setelah dilakukan pemijatan perineum hanya 21,4\% sementara pada kelompok kontrol $71,4 \%$ dengan hasil $\mathrm{p}=0,02(<0,05)$.

Menurut Beckmann dan Garrett (2009), pijat perineum pada saat antenatal dimulai dari kehamilan $35 \mathrm{mg}$ akan mengurangi kemungkinan trauma perineum yang memerlukan jahitan. Pijat perineum juga bermanfaat untuk menghilangkan nyeri perineum setelah persalinan serta kompres hangat jaringan pada pijat perineum selama kurang-lebih 10 menit akan meningkatkan sirkulasi darah sehingga otot-otot di daerah perineum kendur (tidak berkontraksi atau tegang).

Hasil penelitian ini sama dengan yang dilakukan oleh Shipman dkk yaitu pijat perineum dalam periode antenatal dapat membantu mengurangi resiko laserasi kedua dan ketiga.

Menurut Johanson, dokter kandungan dari Nort Staffordshire Maternity Hospital, Inggris, mencatat Ibu yang rajin melakukan pemijatan perineum sejak tiga bulan sebelum persalinan hampir tidak terjadi robekan pada saat persalinan. Kalaupun terjadi robekan perineum secara alamiah, maka luka akan pulih dengan cepat.

Aprilia mengemukakan bahwa pada saat ibu dilakukan pemijatan perineum jaringan pada perineum menjadi rileks sehingga dapat menyebabkan peningkatan elastisitas jalan lahir yang dapat mempermudah proses melahirkan serta mengurangi kejadian robekan perineum.

Chapman mengemukan bahwa pemijatan perineum juga dapat sebagai mekanisme koping bagi ibu yaitu untuk menghilangkan rasa takut dan cemas saat persalinan karena selama kehamilan jaringan disekitar perineum sudah dilakukan pemijatan perineum sehingga jaringan disekitar perineum menjadi elastis.

Menurut Danuatmaja, bahwa pemijatan perineum yang dilakukan sejak bulan-bulan terakhir kehamilan menyiapkan jaringan kulit perineum lebih elastis sehingga lebih mudah meregang. Selain itu meningkatkan elastisitas vagina untuk membuka, sekaligus melatih ibu untuk aktif mengendurkan perineum ketika ia merasakan tekanan saat kepala bayi lahir. Ini dapat mengurangi robekan perineum, mengurangi pemakaian episiotomi, dan mengurangi penggunaan alat bantu persalinan lainnya (Danuatmaja B, 2008).

Banyak ibu merasakan perubahan daya regang daerah perineumnya setelah satu atau dua minggu pemijatan.

Ketidak adekuatan elastisitas perineum merupakan faktor maternal yang sangat berpengaruh terhadap terjadinya ruptur perineum maupun tindakan episiotomi (Cunningham, 2013).

Robekan perineum banyak dicemaskan ibu hamil menjelang persalinannya, namun hal ini bisa terkurangi 
resikonya dengan cara melatih elastisitas perineum. Ibu bisa memijat daerah perineum dengan cara yaitu berikan pelumas pada jari, letakan ibu jari pada perineum, tekan dengan lembut dan perlahan perineum kearah rectum (anus), kearah samping dan lakukan hal ini dengan baik dan teratur (Chomaria, 2012).

Menurut Barrett et al, peregangan perineum dan robekan pada perineum selama proses persalinan dapat melemahkan otot-otot dasar panggul serta dinding vagina, trauma pada perineum juga menimbulkan rasa tidak nyaman dan nyeri pada saat melakukan hubungan seksual. Maka perlunya dilakukan pemijatan perineum pada saat kehamilan

Peregangan pada perineum saat persalinan bisa mengakibatkan perubahan yang positif apabila perineum elastis, fleksible dan lentur maka kejadian ruptur perineum dapat diminimalisir atau tidak terjadi ruptur perineum sama sekali (perineum utuh) dan perubahan yang negatif apabila perineum tidak elastis, fleksible dan lentur maka regangan pada perineum akan mengakibatkan terjadi ruptur perineum. Maka salah satu cara yang dilakukan untuk menghindari terjadinya ruptur perineum dengan melakukan pemijatan perineum (Andarmoyo S, 2013).

Hal ini membuktikan manfaat pemijatan perineum yang dapat membantu melunakkan jaringan perineum sehingga jaringan tersebut akan membuka tanpa resistensi pada saat persalinan, untuk mempermudah lewatnya bayi. Pemijatan perineum ini memungkinkan untuk melahirkan bayi dengan perineum tetap utuh. Pemijatan perineum adalah teknik memijat perineum pada waktu hamil atau beberapa minggu sebelum melahirkan guna meningkatkan aliran darah ke daerah ini dan meningkatkan elastisitas perineum. Peningkatan elastisitas perineum akan mencegah kejadian robekan perineum maupun episiotomi (Fraser M, 2009).

\section{KESIMPULAN DAN REKOMENDASI}

Berdasarkan hasil penelitian dapat disimpulkan bahwa pijat perineum dapat mencegah terjadinya ruptur perineum pada persalinan normal antara kelompok intervensi dan kelompok kontrol. Pijat perineum yang dilakukan dengan benar sebanyak 5 kali dalam seminggu secara rutin dengan lama 5-10 menit setiap hari pada kelompok intervensi yaitu primigravida mulai usia kehamilan minimal 35-36 minggu sampai persalinan dapat mengurangi angka kejadian ruptur perineum secara spontan. Pada kelompok intervensi mengalami ruptur lebih kecil 4 orang (26,67\%) dibandingkan kelompok kontrol yang mengalami ruptur perineum10 orang $(66,67 \%)$. Sehingga pijat perineum dapat diterapkan pada ibu hamil terutama ibu primigravida fisiologis mulai usia kehamilan 35/36 minggu untuk mencegah terjadinya ruptur perineum.

Beberapa masukan yang dapat diberikan yaitu, Bagi Institusi Pendidikan Diharapkan dapat menambahan sumber referensi atau bahan informasi tentang pijat perineum; Bagi Profesi Kebidanan Diharapkan memberikan sumbangan ilmu bagi ilmu kebidanan sebagai bahan pertimbangan dalam memberikan asuhan kebidanan mengenai pijat perineum selama kehamilan sehingga dapat memanimalisir angka kejadian ruptur perineum; Bagi Masyarakat Diharapkan kepada Ibu hamil trimester III untuk meningkatkan pengetahuan tentang pijat perineum dari buku, majalah, informasi media elektronik (radio, televisi, internet) dan mengikuti penyuluhan atau kegiatan yang diadakan di BPM Ny "I" Cipageran Cimahi Utara kota Cimahi. 


\section{REFERENSI}

1. Andarmoyo S, Suharti. 2013, Persalinan Tanpa Nyeri Berlebihan, AR-Ruzz Media, Jogjakarta.

2. Aprilia. Y, 2010, Hipnostetri : Rileks, Nyaman, dan Aman Saat Hamil \& Melahirkan, Gagasmedia, Jakarta.

3. Arikunto. S, 2013, Prosedur Penelitian, Rineka Cipta, Jakarta.

4. Barrett G, Pendry E, Peacock J, Victor C, Thakar R, Manyonda I. Women's sexual health after childbirth. BJOG: an international journal of obstetrics and gynaecology 2000; 107(2):186-95.

5. Beckmann MM, Stock OM. Antenatal Perineal Massage For Reducing Perineal Trauma. Cochrane Database of Systematic Reviews 2013, Issue 4. Art. No.: CD005123. DOI: 10.1002/14651858.CD005123.pub.

6. Chapman, 2006, Asuhan kebidanan dan kelahiran, EGC, Jakarta.

7. Chomaria. N, 2012, Melahirkan Tanpa rasa sakit, Kompas Gramedia, Jakarta.

8. Cunningham, Ph.D., Michael R. Kramer, Ph.D., Solveig A dan K.M. Venkat Narayan, M.D 2014, Obstetri Willaims. 23rd ed. United States of America:The McGraw Hill Companies.

9. Danuatmaja, B., M. Meiliasari. 2007. Persalinan Normal Tanpa Rasa Sakit, Pusra Sehat, Jakarta.

10. Depkes RI. 2012. Profil Kesehatan Republik Indonesia Tahun 2012.(Online). Tersedia : http://www.depkes.go.id. 15 Desember 2018

11. Departemen Kesehatan RI. 2008. Profil kesehatan Indonesia 2007. Jakarta : Depkes RI Jakarta .

12. Dinkes Jabar, 2016, AKI dan AKB Berdasarkan Dinas Kesehatan Jawa Barat. http://jabarprov.go.id/index.php diperoleh tanggal 17 Desember 2018.

13. Dinkes Kota Cimahi, 2016, Angka Kematian Ibu dan Bayi.

14. Enggar. 2009. Prinsip Kerja Alat Penggorengan Vakum., Jurnal Agrikultura vol 12 nomor 6 tahun 2009, ISSN 0853-2885, Fakultas Pertanian, Universitas Padjajaran.

15. Fraser M, Cooper AM. Myles. 2009. Buku Ajar Bidan Edisi ke-14. Jakarta: EGC.

16. Herdiana, T. 2007. Tips pijat perineum, EGC, Jakarta.

17. Hermiyanti, S. 2010. Buku Ajar Ginekologi, EGC Jakarta.

18. Hurlock, E. B. 2011. Psikologi Perkembangan : Suatu Pendekatan Sepanjang Rentang Kehidupan, Erlangga, Jakarta.

19. Indivara. 2009. Panduan senam hamil, Rineka Cipta, Jakarta.

20. Johanson. Vacuum extraction versus forceps for assisted vaginal delivery. Cochrane Database of Systematic Reviews, Issue 2. DOI: 10.1002/14651858.CD000224.1999:345-56

21. Mochtar, R. 2011. Sinopsis Obstetri, EGC, Jakarta.

22. Norwitz, E. \& Schorge, J. 2008. At A Glance Obstetri dan Ginekologi, Erlangga, Jakarta.

23. Notoatmodjo, S. 2012. Metodologi Penelitian Kesehatan, Rineka Cipta, Jakarta.

24. Shipman MK, Boniface DR, Tefft ME, McCloghry F. Antenatal perineal massage and subsequent perineal outcomes: a randomised controlled trial. British Journal of Obstetrics and Gynaecology.1997;104(7):87-91. 
25. Sugiyono. 2011. Metode Penelitian Kuantitatif, Kualitatif dan $R \& D$, Afabeta, Bandung.

26. Survey Demografi dan Kesehatan Indonesia (SDKI). 2012. Angka Kematian Ibu. Dikutip dari www.bkkbn.co.id diakses pada tanggal 15 Desember 2018

27. Survey Demografi dan Kesehatan Indonesia (SDKI). 2014. Angka Kematian Bayi. Dikutip dari www.bkkbn.co.id diakses pada tanggal 15 Desember 2018

28. Wewet, S, Ermawati, Elda Yusefni, Pengaruh Pemijatan Perineum pada Primigravida terhadap Kejadian Ruptur Perineum saat Persalinan di Bidan Praktek Mandiri di Kota Bengkulu Tahun 2014, Jurnal Kesehatan Andalas.2015;4(1).http://jurnal.fk.unand. ac.id/index.php/jka.

29. WHO, 2013, Maternal Mortality. Retrieved November 15, 2018, from www.who.com.

30. Wiknjosastro, H. 2010. Ilmu Kandungan, Yayasan Bina Pustaka Sarwono Prawirohardjo, Jakarta.

31. Yanti. 2010. Buku Ajar Asuhan Kebidanan Persalinan, Pustaka Rihama, Yogyakarta 